\title{
Glycerol treatment as recovery procedure for cryopreserved human skin allografts positive for bacteria and fungi
}

\author{
Gilbert Verbeken • Gunther Verween • Daniel De Vos • Bruno Pascual • \\ Peter De Corte $\cdot$ Cornelia Richters $\cdot$ Arlette De Coninck $\cdot$ Diane Roseeuw $\cdot$ \\ Nadine Ectors $\cdot$ Thomas Rose $\cdot$ Serge Jennes $\cdot$ Jean-Paul Pirnay
}

Received: 31 August 2010/Accepted: 16 February 2011/Published online: 1 March 2011

(C) The Author(s) 2011. This article is published with open access at Springerlink.com

\begin{abstract}
Human donor skin allografts are suitable and much used temporary biological (burn) wound dressings. They prepare the excised wound bed for final autografting and form an excellent substrate for revascularisation and for the formation of granulation tissue. Two preservation methods, glycerol preservation and cryopreservation, are commonly used by tissue banks for the long-term storage of skin grafts. The burn surgeons of the Queen Astrid Military Hospital preferentially use partly viable cryopreserved skin allografts. After mandatory 14-day bacterial and mycological culture, however, approximately $15 \%$ of
\end{abstract}

G. Verbeken $(\bowtie) \cdot$ G. Verween · D. De Vos .

B. Pascual · P. De Corte · T. Rose · J.-P. Pirnay

Skin- and Keratinocyte Bank, Laboratory for Molecular and Cellular Technology, Burn Wound Centre, Queen

Astrid Military Hospital, Brussels, Belgium

e-mail: gilbert.verbeken@mil.be

C. Richters

Euro Skin Bank, Beverwijk, The Netherlands

A. De Coninck · D. Roseeuw

Department of Dermatology and Pathology, UZ Brussel,

Vrije Universiteit Brussel, Brussels, Belgium

\section{N. Ectors}

Tissue Banks University Hospitals Leuven, Katholieke Universiteit Leuven, Leuven, Belgium

\section{S. Jennes}

Burn Wound Centre, Queen Astrid Military Hospital, Brussels, Belgium the cryopreserved skin allografts cannot be released from quarantine because of positive culture. To maximize the use of our scarce and precious donor skin, we developed a glycerolisation-based recovery method for these culture positive cryopreserved allografts. The inactivation and preservation method, described in this paper, allowed for an efficient inactivation of the colonising bacteria and fungi, with the exception of spore-formers, and did not influence the structural and functional aspects of the skin allografts.

Keywords Skin banking - Skin allograft . Cryopreservation - Glycerol preservation - Bacterial and fungal contamination - Bacterial and fungal decontamination

Human allograft skin is generally used to effect a temporary (it will mostly be rejected) wound closure on full thickness (burn) wounds. It acts as a mechanical and biological barrier and thus decreases the loss of water, protein, and heat through the (burn) wound (Mackie 2002; Kearney 2005; Leon-Villapalos et al. 2010). Human allograft skin can be preserved by numerous methods: cool storage, cryopreservation, lyophilisation and dehydration (e.g. glycerolisation). These methods amount to different ranges of allograft skin viability, integrity and immunogenicity. In some cases a certain level of allograft skin viability, integrity and permeability is 
required, but often skin allografts do not need to be viable at any expense.

Glycerol or propylene glycol preserved allograft skin, for example, is non-viable and has been used successfully in burn surgery for decades (Kreis et al. 1989; de Backere 1994; Huang et al. 2004; Khoo et al. 2010). Glycerolisation was shown to attenuate allograft antigenicity (Hettich et al. 1994; Richters et al. 1997), and thus extend the period of graft take, and to inhibit bacteria and viruses (Marshall et al. 1995; Saegeman et al. 2008). On the down side, glycerolized skin tends to be more rigid than fresh or cryopreserved skin. Hence, glycerolised donor skin is usually not the first choice of temporary biological dressing of the burn surgeons of the Burn Wound Centre of the Queen Astrid Military Hospital (BWCQAMH).

Cryopreservation has been shown to maintain a degree of viability and the basic physiochemical and permeability properties of fresh human skin (Aggarwal et al. 1985). First reports of frozen skin storage date from before the Second World War (Mider and Morton 1939). In 1952, Billingham and Medawar described the cryopreservation of skin using glycerol as cryoprotectant. Since then many protocols for skin cryopreservation have been developed, based on the use of a variety of cryoprotectants and constant-rate cooling using commercially available programmable controlled-rate freezers (Biagini et al. 1979; Kets et al.1985; Kearney et al. 1990; Ingham et al. 1993; Bravo et al.2000; Alotto et al. 2002; Franchini et al. 2009; Pianigiani et al. 2010). The physicians in our centre have the experience that cryopreserved and partly viable donor skin allografts generate extra beneficial effects, mainly a better up granulation of the wound bed in comparison with glycerolised skin. They also observed that partly viable cryopreserved allograft skin stimulates wound healing in superficial burn wounds in children, thus preventing autografting. This could be due to the fact that living skin cells can deliver organisational signals or growth factors to the wound bed, thus mediating the formation of granulation tissue or the stimulation of wound healing (Galkowska et al. 2006) in the same way as do cultured allogenic keratinocytes and fibroblasts (Roseeuw et al. 1990; Duinslaeger et al. 1996; Goedkoop et al. 2010). Down side of the cryopreservation methods, however, is that they tend to support bacterial and fungal survival, which can be problematic in the case of skin allograft preservation. The only variables significantly affecting microbiological contamination of donor skin allografts are the type of donor (live or dead) and the type of processing (cryo- or glycerol preservation), with highest levels of contamination found in cryopreserved cadaveric donor skin (Pianigiani et al. 2010). In contrast to some other harvested donor tissues (e.g. bone, tendons and heart valves), skin tissue is inherently colonised by skin associated micro-organisms and thus non-sterile at the time of harvesting. Superficial decontamination of the donor's skin before harvesting, using antiseptics, is not indefectible. Therefore, in the BWC-QAMH, freshly harvested (post mortem) donor skin is collected in an antibiotics containing transport solution. This transport solution is composed of $800 \mathrm{ml}$ custom made Medium for Culturing of Epithelial Cells (MCEC, Gibco Invitrogen Corporation) supplemented with $200 \mathrm{ml}$ of custom made Cambridge Antibiotic Solution (CAS, Inverclyde Biologicals). MCEC consists of 3:1 ratio of DMEM/Ham's F12 Nutrient mix and $10.6 \mathrm{~g} / \mathrm{l}$ sodium bicarbonate, while CAS consists of Gentamicin sulphate (4 g/l), Primaxin (0.2 g/l), Polymyxin B (0.2 g/l), Vancomycin $(0.05 \mathrm{~g} / \mathrm{l})$ and Nystatin $(2,500,000 \mathrm{U} / \mathrm{l})$ in Medium 199 with $25 \mathrm{mM}$ HEPES. The harvested donor skin allografts are kept in this transport solution (static container) for minimum $24 \mathrm{~h}(\max .72 \mathrm{~h})$ at $2-8^{\circ} \mathrm{C}$, before further processing.

The European Human Cell and Tissue Directives (2004/23/CE, 2006/17/CE and 2006/86/CE) were recently (December 19, 2008) transposed to Belgian Law. To be accredited, Belgian banks for human body materials have to comply with quality and safety criteria defined in Royal Decrees (September 28, 2009). In addition, the Belgian Superior Health Council published (October 1, 2008) quality- and safety criteria for human skin allografts. The skin bank of the Queen Astrid Military Hospital is EN ISO 9001: 2008 certified for the full scope of its activities. Implementing this kind of relevant Quality Management Systems is important, also for tissue bankers (von Versen et al. 2000).

In Belgium, human donor skin allografts are tested for bacterial and mycological contamination using a protocol based on 14-day microbiological cultures. Culture-positive skin allografts can only be released for clinical use if growth of non-pathogens appeared 
post 7-days of culture. In our skin bank this results in a donor rejection rate (due to positive cultures) of approximately $15 \%$ of cryopreserved skin donations, which is in line with the expectations (Rooney et al. 2008). The CAS containing transport solution was (since it's introduction in 2009) not capable of decontaminating the harvested fresh donor skin in 5 of $34(14.7 \%)$ skin donations. The drug sensitivity patterns revealed that these bacteria were sensitive (in vitro) to at least one of the antibiotics present in the CAS-cocktail. As to why the cocktail was not efficient in some cases, we can think of two likely causes. First of all, bacteria can be hidden deep into the harvested skin (e.g. in the dept of the hairfollicles) where the antibiotics can't reach them in due time and, secondly, the optimal operating temperature of these antibiotics is much closer to $36^{\circ} \mathrm{C}$ than to $2-8^{\circ} \mathrm{C}$.

Recently, we decided to develop and implement a recovery procedure for the cryopreserved skin allografts that tested positive for bacteria and fungi.

Multiple publications describe the antimicrobial effect of glycerol and the use of glycerol as an inactivation agent for culture positive skin allografts (de Backere 1994; Hoekstra et al.1994; van Baare et al. 1994; Marshall et al. 1995; Richters et al. 1996; Mackie 1997; Saegeman et al. 2008). The hitherto published glycerol preservation and decontamination methods generally use high glycerol concentrations and elevated incubation temperatures and periods. We used the most recently published glycerol inactivation protocol (Saegeman et al. 2008) as a starting point for our own development. Saegeman and coworkers investigated the inhibiting effect of glycerol on bacterial suspensions (not on contaminated skin samples) in relation to the glycerol concentration and incubation temperature and time. They observed that no bacterium, with the exception of one spore-former (Bacillus subtilis) survived more than 14 days in the test-tubes with $85 \%$ glycerol at $36^{\circ} \mathrm{C}$.

We transposed these findings to an inactivation method for the bacteria and fungi in our culture positive cryopreserved skin allografts. Twenty-one thawed (water bath at $37^{\circ} \mathrm{C}$ ) culture positive skin donations were incubated in 50\% glycerol (Pharma Belgium) in Hartmann's solution (Baxter) for 2-24 h at $36^{\circ} \mathrm{C}$, followed by long-term storage in $85 \%$ glycerol in Hartmann's solution at $36^{\circ} \mathrm{C}$ (Fig. 1). Skin allografts had been previously routinely

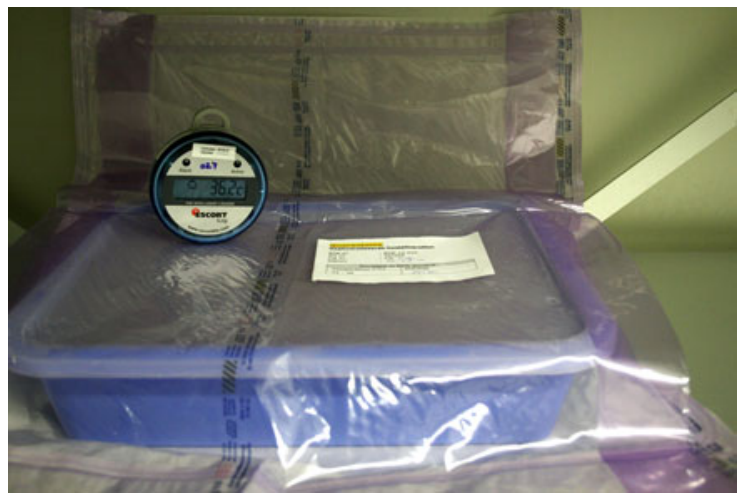

Fig. 1 Incubation of skin allografts in $85 \%$ glycerol at $36^{\circ} \mathrm{C}$

cryopreserved in 30\% glycerol in Hartmann's solution at $<-135^{\circ} \mathrm{C}$ (vapour of liquid nitrogen) (Kets et al. 1985).

After 5-6 weeks of incubation, several representative samples of $10-20 \mathrm{~cm}^{2}$ each were rinsed in $0.9 \% \mathrm{NaCl}$ and submitted to 14-day bacteriological and mycological cultures in thioglycolate (with resazurine, bioMérieux) and Sabouraud (bioMérieux) broth, respectively. In case of a positive culture, the $85 \%$ glycerol solution was renewed and incubation at $36^{\circ} \mathrm{C}$ was resumed. After 5-6 months new samples

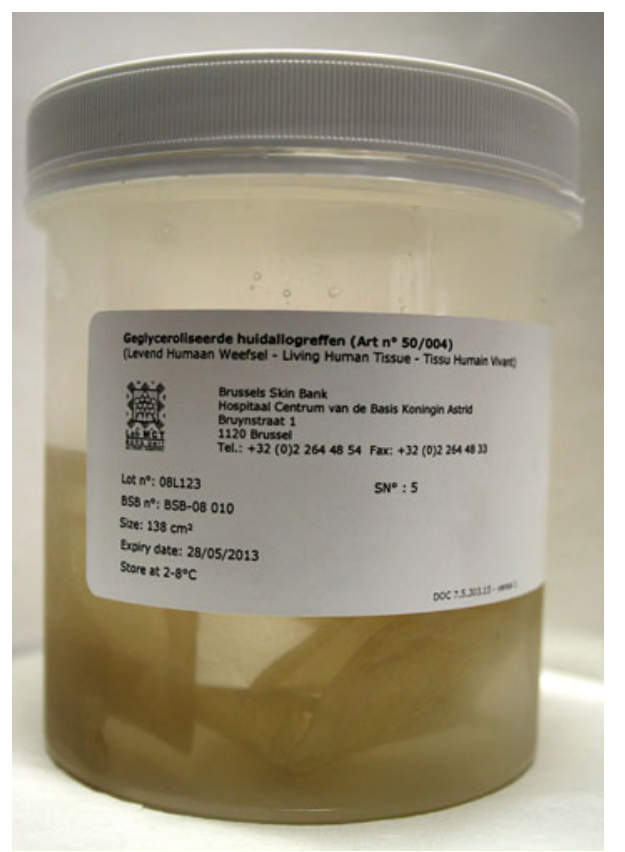

Fig. 2 A vial containing glycerolised skin allografts and labelled with donor references, lot number, sizes and expiry date 
were taken and tested. A skin donation was released and transfered to final sterile (closed and locked) storage recipients (Fig. 2) upon negative 14-day cultures. Since the glycerolisation procedure had significantly reduced the initial donor skin surface (up to $15 \%$ ), skin allografts were remeasured before final packaging.
After 5-6 months all donations scored negative in 14-day bacterial and mycological testing, except one (containing Bacillus sp.), which was definitively rejected and destroyed (Table 1). The structural integrity of the rehydrated glycerolisation-recovered cryopreserved skin allografts was evaluated. Sections (Bouin fixation followed by haematoxylin eosin

Table 1 Glycerol decontamination of skin allografts positive for bacteria and fungi

\begin{tabular}{|c|c|c|c|c|}
\hline & \multirow{2}{*}{$\begin{array}{l}\text { Donor } \\
\text { code }\end{array}$} & \multicolumn{3}{|l|}{ 14-day bacteriological and mycological culture } \\
\hline & & Before glycerolisation & $\begin{array}{l}\text { 5-6 week } \\
\text { glycerolisation }\end{array}$ & 5-6 month glycerolisation \\
\hline \multirow{21}{*}{$\begin{array}{l}\text { Transposed } \\
\text { Saegeman } \\
\text { protocol }\end{array}$} & 08010 & Pseudomonas aeruginosa & No growth & Not done \\
\hline & 08019 & Staphylococcus capitis & No growth & Not done \\
\hline & 08031 & Candida albicans & No growth & Not done \\
\hline & 08033 & Staphylococcus epidermidis & No growth & Not done \\
\hline & 08034 & Proteus mirabilis, Pseudomonas aeruginosa & No growth & Not done \\
\hline & 08036 & Escherichia coli & No growth & Not done \\
\hline & 08037 & Pseudomonas aeruginosa & No growth & Not done \\
\hline & 08038 & Enterobacter cloacae & No growth & Not done \\
\hline & 08039 & Staphylococcus epidermidis, Staphylococcus capitis & No growth & Not done \\
\hline & 08040 & $\begin{array}{l}\text { Klebsiella pneumoniae, Escherichia coli, Enterococcus } \\
\text { faecalis, Staphylococcus capitis, Staphylococcus } \\
\text { haemolyticus }\end{array}$ & No growth & Not done \\
\hline & 08042 & Staphylococcus aureus & No growth & Not done \\
\hline & 08043 & Staphylococcus apidermidis, Candida albicans & No growth & Not done \\
\hline & 08047 & Proteus mirabilis, Staphylococcus aureus, Candida albicans & No growth & Not done \\
\hline & 08050 & Staphylococcus epidermidis & No growth & Not done \\
\hline & 08051 & Staphylococcus epidermidis, Candida albicans & No growth & Not done \\
\hline & 08052 & Candida glabrata & No growth & Not done \\
\hline & 08053 & Staphylococcus capitis & No growth & Not done \\
\hline & 08054 & Staphylococcus epidermidis, Staphylococcus warneri & No growth & Not done \\
\hline & 08056 & Staphylococcus epidermidis & $\begin{array}{l}\text { Staphylococcus } \\
\text { epidermidis }\end{array}$ & $\begin{array}{l}\text { Bacillus sp. (skin graft } \\
\text { was rejected and } \\
\text { destroyed) }\end{array}$ \\
\hline & 08062 & Staphylococcus capitis & No growth & Not done \\
\hline & 09001 & Klebsiella pneumoniae & No growth & Not done \\
\hline \multirow{8}{*}{$\begin{array}{l}\text { Optimised } \\
\text { Saegeman } \\
\text { protocol }\end{array}$} & 09017 & Escherichia coli & No growth & Not done \\
\hline & 09018 & Escherichia coli & No growth & Not done \\
\hline & 09023 & Staphylococcus epidermidis & $\begin{array}{l}\text { Staphylococcus } \\
\text { epidermidis }\end{array}$ & $\begin{array}{l}\text { Bacillus sp. (skin graft } \\
\text { was rejected and } \\
\text { destroyed) }\end{array}$ \\
\hline & 09034 & Staphylococcus epidermidis & No growth & Not done \\
\hline & 09050 & Candida albicans & No growth & Not done \\
\hline & 10004 & Candida albicans, Enterococcus faecum & No growth & Not done \\
\hline & 10005 & Candida albicans & No growth & Not done \\
\hline & 10015 & Clostridium perfringens & No growth & Not done \\
\hline
\end{tabular}


staining and PAS reaction) of "direct glycerolisation only", "direct cryopreservation only" and "glycerolisation after cryopreservation" skin samples were evaluated under a microscope and compared (blind) by an experienced dermato-pathologist. This evaluation was based on the pigmentation, presence and integrity of hair follicles and their associated muscles, sweat and sebaceous glands, and the dermal-epidermal junction and the presence of apoptotic and/or necrotic cells, sentinels of local tissue stress and inflammation. No differences were observed between the structural features of the allografts that were immediately glycerolised or only cryopreserved and those that were cryopreserved prior to glycerolisation. Hair follicles and sweat and sebaceous glands were clearly present. The samples harboured neither apoptotic nor necrotic cells and showed a normal pigmentation and an intact dermal-epidermal junction. A more elaborate description and discussion on the functional and structural integrity of those retain samples was published earlier in this journal by Verbeken et al. (2010).

Upon this satisfactory structural and histological evaluation, our burn surgeons started to use the recovered allografts in routine. Surprisingly, they observed that the grafts did not resist well to shearing forces when meshed (skin is fenestrated to allow drainage and expansion); the epithelium detached from the dermis (epidermolysis) once rinsed in physiological solution $(0.9 \% \mathrm{NaCl})$ prior to use. Because the epidermis is not an absolute requirement

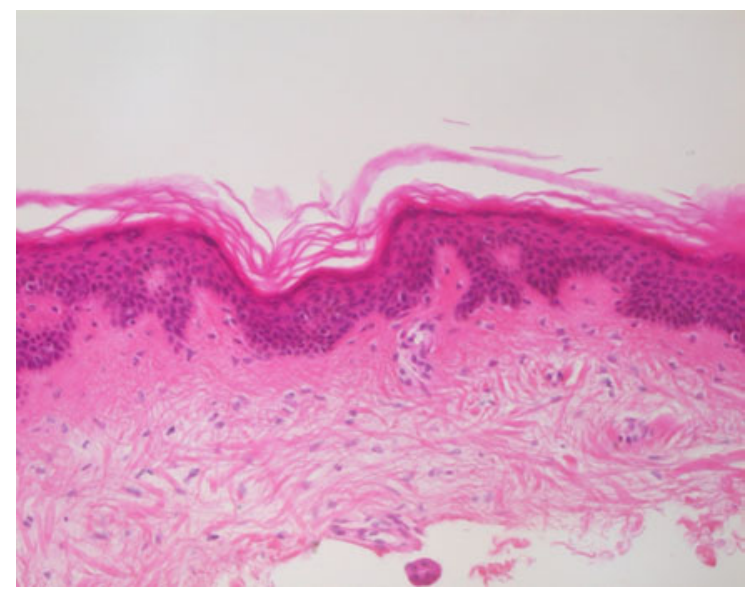

Fig. 3 Micrograph $(200 \times)$ of a haematoxylin eosin and PAS reaction stained section of a rehydrated skin sample that was thawed after 10 years of cryopreservation at $<-135^{\circ} \mathrm{C}$ for the proper functioning of meshed allograft skin, surgeons reported this as a minor event without clinical impact for the grafted patients. We preferred, however, to further optimise our glycerolisationrecovery protocol and to solve the epidermolysis problem. We suspected that epidermolysis was mainly due to the long storage at relatively high temperature $\left(36^{\circ} \mathrm{C}\right)$. Therefore we reduced the $50 \%$ glycerol incubation temperature to $2-8^{\circ} \mathrm{C}$ and reduced the $85 \%$ glycerol incubation period at $36^{\circ} \mathrm{C}$ to $2.5 \mathrm{~h}$, followed by long time incubation in $85 \%$ glycerol at $2-8^{\circ} \mathrm{C}$. Eight culture positive skin donations were treated according to this modified

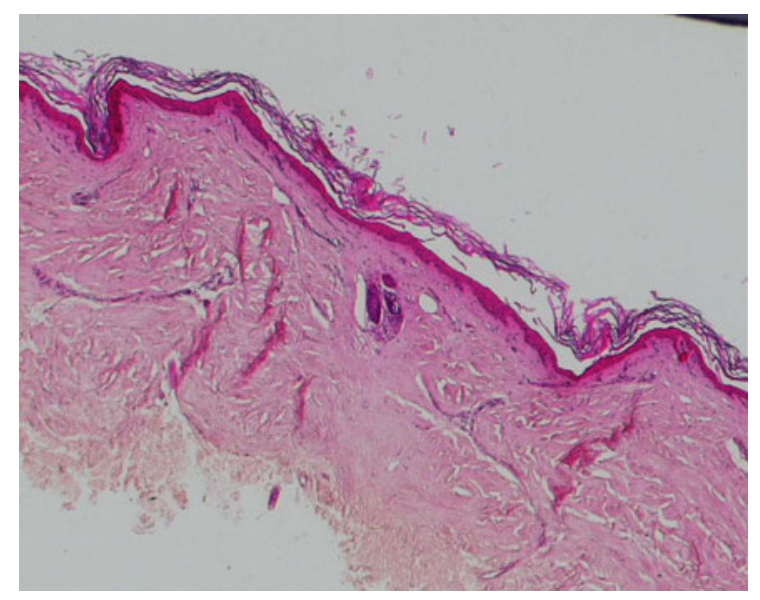

Fig. 4 Micrograph $(200 \times)$ of a haematoxylin eosin and PAS reaction stained section of a rehydrated skin sample that was glycerolised, without previous cryopreservation

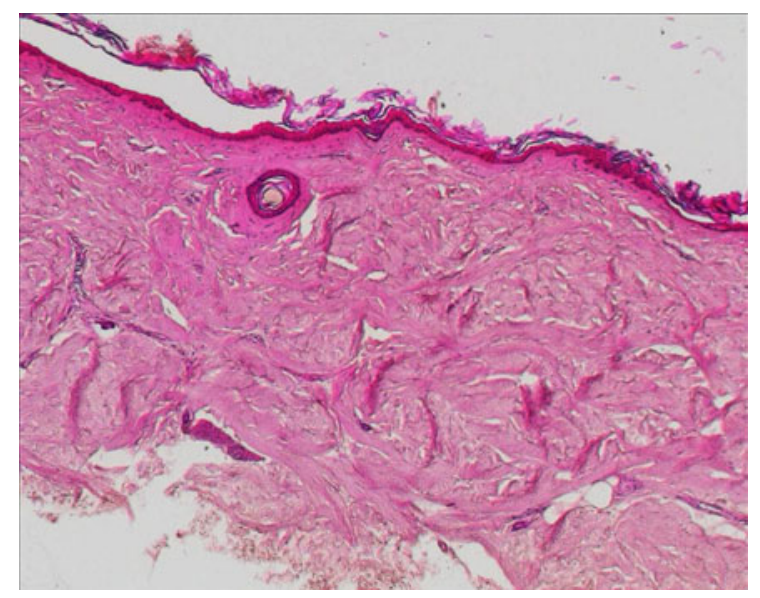

Fig. 5 Micrograph $(200 \times)$ of a haematoxylin eosin and PAS reaction stained section of a rehydrated skin sample that was thawed after 14 weeks of cryopreservation at $<-135^{\circ} \mathrm{C}$ and subsequently glycerolised (optimised protocol) 


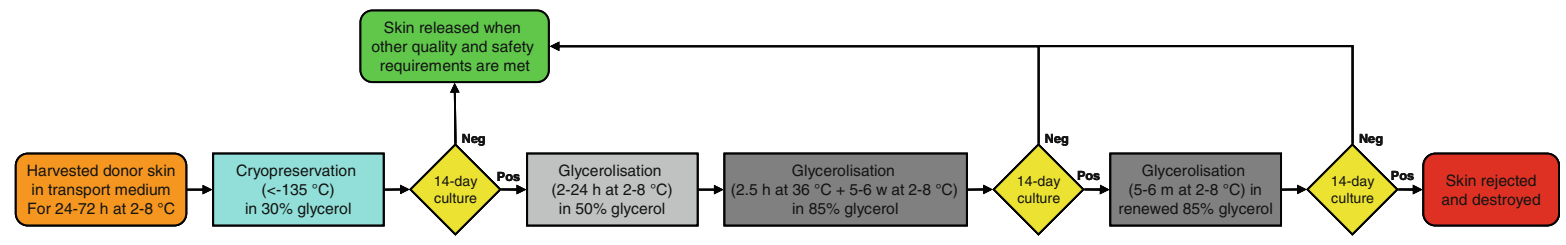

Fig. 6 Flow chart of the glycerolisation-based recovery procedure for cryopreserved human skin allografts that tested positive in bacterial and mycological culture

protocol. With the exception of one (again containing Bacillus sp.), all skin donations were successfully decontaminated (Table 1) and, as could be expected, all samples exhibited normal structural aspects. Microscopical pictures show a piece of hydrated skin that was only cryopreserved (Fig. 3), one that was only glycerolised (Fig. 4) and one that was glycerolised ("decontaminating-glycerolisation") after thawing (Fig. 5). This time the surgeons who used the skin grafts and the technicians and nurses who processed and prepared the grafts did not observe any mechanical or structural abnormalities, such as epidermolysis, when recovered skin allografts were meshed and rehydrated. Preliminary clinical observations $\left(7555 \mathrm{~cm}^{2}\right.$ of glycerolisation-recovered skin was grafted) indicate that there are no effects on the functional characteristics of the donor skin.

Although the physicians of the BWC-QAMH usually prefer to use the more elastic, viable and presumably wound healing-stimulating cryopreserved skin, for some indications they opt for the less immunogenic glycerolised skin. Today, the skin bank can provide them with both types of allograft skin whilst recycling most of the culture positive cryopreserved skin allografts. Contamination with spore-formers remains however problematic. This results in an optimal use of the scarce and precious harvested donor skin (Fig. 6). The described protocol could also be of interest to tissue bankers using glycerolisation as main or sole method of preservation or to researchers involved in the development of human skin equivalents (Richters et al. 2008; Böttcher-Haberzeth et al. 2010; van der Veen et al. 2010).

Open Access This article is distributed under the terms of the Creative Commons Attribution Noncommercial License which permits any noncommercial use, distribution, and reproduction in any medium, provided the original author(s) and source are credited.

\section{References}

Aggarwal SJ, Baxter CR, Diller KR (1985) Cryopreservation of skin: an assessment of current clinical applicability. J Burn Care Rehabil 6:469-476

Alotto D, Ariotti S, Graziano S, Verrua R, Stella M, Magliacani G, Castagnoli C (2002) The role of quality control in a skin bank: tissue viability determination. Cell Tissue Bank 3:3-10

Biagini G, Poppi V, Cocchia D, Ruboli G, Damiani R, Laschi R (1979) Skin storage in liquid nitrogen. An ultrastructural investigation. J Cutan Pathol 6:5-17

Billingham RE, Medawar PB (1952) The freezing, drying and storage of mammalian skin. J Exp Biol 29:454

Böttcher-Haberzeth S, Biedermann T, Reichmann E (2010) Tissue engineering of skin. Burns 36:450-460

Bravo D, Rigley TH, Gibran N, Strong DM, Newman-Gage H (2000) Effect of storage and preservation methods on viability in transplantable human skin allografts. Burns 26:367-378

de Backere AC (1994) Euro skin bank: large scale skin-banking in Europe based on glycerol-preservation of donor skin. Burns 20:S4-S9

Duinslaeger L, Verbeken G, Reper P, Delaey B, Vanhalle S, Vanderkelen A (1996) Lyophilized keratinocyte cell lysates contain multiple mitogenic activities and stimulate closure of meshed skin autograft-covered burn wounds with efficiency similar to that of fresh allogeneic keratinocyte cultures. Plast Reconstr Surg 98:110-117

Franchini M, Zanini D, Bosinelli A, Fiorini S, Rizzi S, D’Aloja C, Vassanelli A, Gandini G, Aprili G (2009) Evaluation of cryopreserved donor skin viability: the experience of the regional tissue bank of Verona. Blood Transfus 7:100-105

Galkowska H, Wojewodzka U, Olszewski WL (2006) Chemokines, cytokines, and growth factors in keratinocytes and dermal endothelial cells in the margin of chronic diabetic foot ulcers. Wound Rep Reg 14:558-565

Goedkoop R, Juliet R, You PH, Daroczy J, de Koos KP, Lijnen R, Rolland E, Hunziker T (2010) Wound stimulation by growth-arrested human keratinocytes and fibroblasts: HP802-247, a new-generation allogeneic tissue engineered product. Dermatology 220:114-120

Hettich R, Ghofrani A, Hafemann B (1994) The immunogenicity of glycerol-preserved donor skin. Burns 20:S71S76

Hoekstra MJ, Kreis RW, du Pont JS (1994) History of the Euro skin bank: the innovation of preservation technologies. Burns 20:S43-S47 
Huang Q, Pegg DE, Kearney JN (2004) Banking of non-viable skin allografts using high concentrations of glycerol or propylene glycol. Cell Tissue Bank 5:3-21

Ingham E, Matthews JB, Kearney JN, Gowland G (1993) The effects of variation of cryopreservation protocols on the immunogenicity of allogeneic skin grafts. Cryobiology 30:443-458

Kearney JN (2005) Guidelines on processing and clinical use of skin allografts. Clin Dermatol 23:357-364

Kearney JN, Wheldon LA, Gowland G (1990) Effects of cryobiological variables on the survival of skin using a defined murine model. Cryobiology 27:164-170

Kets EH, Vanderkelen AD, Brecx JF (1985) Skin banking. Acta Med Milit Belg 137:167-168

Khoo TL, Halim AS, Saad AZ, Dorai AA (2010) The application of glycerol-preserved skin allografts in the treatment of burn injuries: An analysis based on indications. Burns [Epub ahead of print]

Kreis RW, Vloemans AF, Hoekstra MJ, Mackie DP, Hermans RP (1989) The use of non-viable glycerol-preserved cadaver skin combined with widely expanded autografts in the treatment of extensive third-degree burns. J Trauma 29:51-54

Leon-Villapalos J, Eldardiri M, Dziewulski P (2010) The use of human deceased donor skin allografts in burn care. Cell Tissue Bank 11:99-104

Mackie DP (1997) The Euro Skin Bank: Development and application of glycerol-preserved allografts. J Burn Care Rehabil 18:S7-S9

Mackie DP (2002) Postal survey on the use of glycerol-preserved allografts in clinical practice. Burns 28:S40-S44

Marshall L, Ghosh MM, Boyce SG, MacNeil S, Freedlander E, Kudesia G (1995) Effect of glycerol on intracellular virus survival: implications for the clinical use of glycerolpreserved cadaver skin. Burns 21:356-361

Mider GB, Morton JJ (1939) The effect of freezing in vitro on some transplantable mammalian tumors and on normal rat skin. Am J Cancer 35:502

Pianigiani E, Ierardi F, Cuciti C, Brignali S, Oggioni M, Fimiani M (2010) Processing efficacy in relation to microbial contamination of skin allografts from 723 donors. Burns 36:347-351

Richters CD, Hoekstra MJ, van Baare J, du Pont JS, Kamperdijk EWA (1996) Morphology of glycerol-preserved human cadaver skin. Burns 22:113-116

Richters CD, Hoekstra MJ, van Baare J, du Pont JS, Kamperdijk EW (1997) Immunogenicity of glycerol-preserved human cadaver skin in vitro. J Burn Care Rehabil 18: 228-233

Richters CD, Pirayesh, Hoeksema H, Kamperdijk EWA, Kreis RW, Dutrieux RP, Monstrey S, Hoekstra MJ (2008) Development of a dermal matrix from glycerol preserved allogeneic skin. Cell Tissue Bank 9:309-315

Rooney P, Eagle M, Hogg P, Lomas R, Kearney J (2008) Sterilisation of skin allograft with gamma irradiation. Burns 34:664-673

Roseeuw DI, De Coninck A, Lissens W, Kets E, Liebaers I, Vercruysse A, Vandenberghe Y (1990) Allogeneic cultured epithelial grafts heal chronic ulcers although they do not remain as proved by DNA analyses. J Dermatol Sci $1: 245-252$

Saegeman VS, Ectors NL, Lismont D, Verduyckt B, Verhaegen J (2008) Short- and long-term bacterial inhibiting effect of high concentrations of glycerol used in the preservation of skin allografts. Burns 34:205-211

van Baare J, Buitenwerf J, Hoekstra MJ, du Pont JS (1994) Virucidal effect of glycerol as used in donor skin preservation. Burns 20:S77-S80

van der Veen VC, van der Wal MBA, van Leeuwen MCE, Ulrich MMW, Middelkoop E (2010) Biological background of dermal substitutes. Burns 36:305-321

Verbeken G, Schoeters D, Verween G, De Vos D, Pascual B, De Corte P, Geukens K, De Coninck A, Roseeuw D, Rose T, Jennes S, Pirnay J-P (2010) Potential release of aluminum and other metals by food-grade aluminum foil used for skin allograft cryo preservation. Cell and Tissue Bank. doi:10.1007/s10561-010-9171-y

Von Versen R, Mönig HJ, Salai M, Bettin D (2000) Quality issues in tissue banking: quality management systems-a review. Cell Tissue Bank 1(3):181-192 